\title{
ANALISIS KINERJA KEUANGAN BERDASARKAN METODE EVA STUDI PADA PERUSAHAAN TELEKOMUNIKASI YANG TERCATAT DI BURSA EFEK INDONESIA (BEI) TAHUN 2013
}

\author{
Ni Made Tatsani Widi Arini \\ Jurusan Pendidikan Ekonomi \\ Universitas Pendidikan Ganesha \\ Singaraja, Indonesia \\ e-mail: tatsaniwidi01@gmail.com
}

\begin{abstract}
ABSTRAK
Penelitian ini bertujuan untuk mengetahui (1) nilai NOPAT pada Perusahaan Telekomunikasi yang telah tercatat di BEI tahun 2013, (2) nilai biaya modal pada perusahaan telekomunikasi yang telah tercatat di BEI tahun 2013, (3) kinerja keuangan perusahaan telekomunikasi yang telah tercatat di BEI tahun 2013 ditinjau dengan metode EVA. Jenis penelitian ini adalah deskriptif kuantitatif. Data dikumpulkan dengan metode dokumentasi dan analisis data yang digunakan yaitu analisis EVA. Hasil penelitian menunjukkan (1) nilai NOPAT PT Telekomunikasi Indonesia Tbk. adalah Rp 20.987.000.000.000,00, PT Indosat Tbk. sebesar Rp 841.838.000.000,00, PT Smartfren Tbk. sebesar Rp -1.784.682.909.136,00, PT XL Axiata Tbk. sebesar Rp 1.301.438.000.000,00, PT Bakrie Telecom sebesar Rp 27.320.180.033,00. (2) Biaya modal untuk PT Telekomunikasi Indonesia Tbk. sebesar Rp 10.284.848.546.016,00, PT Indosat Tbk. sebesar Rp 3.273.701.158.489,00, PT Smartfren Tbk. sebesar Rp 790.441.706.857,00, PT XL Axiata sebesar Tbk. Rp 1.670.800.564.235,00, dan biaya modal PT Bakrie Telecom sebesar Rp 196.585.006.260,00. (3) Hasil analisis EVA menunjukkan PT Telekomunikasi Indonesia Tbk. memililki nilai EVA $>0$, ini berarti kinerja keuangan perusahaan telah mampu menciptakan nilai tambah bagi perusahaan. Sedangkan PT Smartfren Tbk., PT Indosat Tbk., PT XL Axiata Tbk., dan PT Bakrie Telecom Tbk. memiliki nilai EVA $<0$, ini menunjukkan bahwa kinerja keuangan perusahaan belum mampu menciptakan nilai tambah bagi perusahaan.
\end{abstract}

Kata Kunci: Biaya Modal, Economic Value Added (EVA), Kinerja Keuangan, Net Operating Profit After Tax (NOPAT).

\begin{abstract}
This research is purpose to understand, (1) the value of NOPAT in the Telecommunications Companies have been listed on BEI in 2013, the value of the cost of capital on a telecommunications companies that have been listed on BEI in 2013, (3) the financial performance of telecommunications companies have been listed on BEI in 2013 revised using EVA method. This type of research is quantitative descriptive. Data collected by documentation method then analyzed using EVA. The result shows (1) the value of NOPAT PT Telekomunikasi Indonesia Tbk. is IDR 20.987.000.000.000, PT Indosat Tbk. IDR 841.838.000.000, PT Smartfren Tbk. IDR -1.784.682.909.136, PT XL Axiata Tbk. IDR 1.301.438.000.000, PT Bakrie Telecom Tbk. IDR 27.320.180.033. (2) The cost of capital for PT Telekomunikasi Indonesia Tbk. is IDR 10.284.848.546.016, PT Indosat Tbk. IDR 3.273.701.158.489, PT Smartfren Tbk. IDR 790441706 857, PT XL Axiata Tbk. IDR 1.670.800.564.235, and the cost of capital of PT Bakrie Telecom Tbk. is IDR 196.585.006.260. (3) The results of EVA analysis indicate PT Telekomunikasi Indonesia Tbk. had EVA>0, this indicates that the financial performance of the company has been able to create added value for the company. Meanwhile, PT Smartfren Tbk. , PT Indosat Tbk., PT XL Axiata Tbk. and PT Bakrie Telecom Tbk. have a value of EVA $<0$, this indicates that the company's financial performance has not been able to create added value for the company.
\end{abstract}

Keyword: Capital of cost, Economic Value Added (EVA), Finance Performance, Net Operating Profit After Tax (NOPAT). 


\section{PENDAHULUAN}

Perkembangan

industri

telekomunikasi tahun 2013 mencapai growth Industry sebesar $7-12 \%$, hal ini menandakan bahwa pasar ini terus bertumbuh baik dalam hal jumlah pelanggan dan jumlah revenue yang didapat dari operator telekomunikasi. Di Indonesia terdapat lima perusahaan yang bergerak di bidang operator telekomunikasi yang telah tercatat di Bursa Efek Indonesia. Perusahaan tersebut yaitu, PT. Telekomunikasi Tbk, PT XL Axiata Tbk, PT Indosat Tbk, PT Smartfren Tbk, dan PT Bakrie Telekom Tbk. Persaingan ke-lima industri ini sudah mencapai posisi zero sum game, yang artinya ketika satu operator tumbuh maka akan memangsa pangsa pasar operator telekomunikasi lainnya. Besarnya persaingan yang terjadi di antara kelima perusahaan ini, memaksa para investor untuk lebih selektif dalam memilih perusahaan yang akan dijadikan tempat untuk menanamkan modalnya.

Investor dalam memutuskan untuk menginvestasikan dananya di pasar modal, terlebih dahulu menilai kinerja keuangan perusahaan yang akan dijadikan tempat untuk berinvestasi. "Kinerja keuangan adalah penentuan ukuran-ukuran tertentu yang dapat mengukur keberhasilan suatu organisasi atau perusahaan dalam menghasilkan laba" (Sawir, 2005:4). Dengan melakukan penilaian kinerja, maka akan diperoleh informasi mengenai kondisi dan posisi keuangan perusahaan (Sawir, 2005). Sumber data yang dapat digunakan investor dalam menilai kinerja keuangan perusahaan dapat dianalisis melalui laporan keuangan yang telah dibuat perusahaan sesuai dengan kaidah standar penyusunan laporan keuangan yang telah ditetapkan.

Menurut Sawir (2005), penilaian kinerja keuangan perusahaan diperlukan untuk menentukan keberhasilan dalam mencapai tujuan perusahaan. Pihak manajemen perusahaan melakukan penilaian kinerja untuk membantu dalam penyusunan rencana usaha perusahaan serta keputusan yang akan diambil untuk masa yang akan datang demi kelangsungan hidup perusahaan. Bagi investor penialain kinerja keuangan sangat berperan dalam menilai tingkat kesehatan keuangan perusahaan dan kondisi sebenarnya suatu perusahaan. Penilaian kinerja keuangan dilakukan agar modal yang diinvestasikan cukup aman dan mendapatkan tingkat hasil pengembalian yang menguntungkan dari investasi yang ditanamkan investor. Penilaian kinerja keuangan dilakukan dengan menganalisis laporan keuangan yang telah dibuat oleh perusahaan. Menurut Warsono (2003), metode analisis laporan keuangan perusahaan yang umum digunakan saat ini yaitu, analisis rasio keuangan, metode Economic Value Added (EVA), analisis balance scorecard, dan analisis RADAR. Pengukuran kinerja keuangan perusahaan yang sering tercantum dalam laporan keuangan perusahaan yang dipublikasikan untuk investor adalah analisis rasio berupa current ratio, Earning per Share (EPS), Return On Investment (ROI), dan Return On Equity (ROE). Pengukuran kinerja dengan menggunakan ROI, EPS, dan ROE dalam operasionalnya menggunakan data yang bersifat historis dan kurang memperhatikan adanya tingkat risiko investasi yang berkaitan dengan biaya modal yang harus ditanggung oleh pemiliki modal itu sendiri (Sawir, 2005). Pengukuran yang belum memperhitungkan adanya unsur biaya modal sendiri atas laba yang dihasilkan akan mengakibatkan pelaporan laba tidak menunjukkan laba yang sebenarnya, karena untuk menghitung laba riil perusahaan harus menghitung biaya modal baik itu modal sendiri maupun modal yang dibiayai dari hutang.

Penilaian kinerja keuangan yang biasanya digunakan sebagaimana yang dipaparkan di atas, dirasa belum cukup oleh pihak manajemen perusahaan maupun bagi investor. Pihak 
manajemen perusahaan belum yakin bahwa perusahaan telah mampu menciptakan nilai tambah perusahaan, sedangkan bagi investor penilaian tersebut belum bisa dipergunakan untuk memprediksi pengembalian modal yang akan diperoleh di masa yang akan datang telah sesuai dengan yang diharapkan. Untuk menanggulangi kelemahan dari analisis rasio yang telah digunakan, maka dapat diterapkan analisis EVA (Economic Value Added) yang dapat memberikan informasi nilai tambah yang dimiliki perusahaan. Informasi nilai tambah perusahaan ini akan lebih meyakinkan investor untuk menanamkan modalnya pada perusahaan.

Metode Economic Value Added (EVA) adalah salah satu cara dalam menilai kinerja keuangan yang lebih memfokuskan pada nilai tambah dari suatu investasi (Sawir, 2005). EVA memberikan tolak ukur seberapa jauh perusahaan telah mampu memberikan nilai tambah kepada pemegang saham dalam satu tahun. Sawir (2005) menyatakan, EVA dapat diperoleh dengan mengurangi laba bersih sebelum pajak dan bunga dengan biaya modal yang dimiliki perusahaan. EVA yang positif menunjukkan bahwa manajemen perusahaan berhasil meningkatkan nilai perusahaan. Lima perusahaan telekomunikasi yang telah tercatat di BEl pada tahun 2013 bersaing sangat ketat dalam memperoleh investor. Persaingan yang ketat diantara perusahaan membuat para investor lebih selektif dalam memilih perusahaan yang akan dijadikan tempat untuk berinvestasi. EVA dapat menjadi salah satu tolak ukur investor untuk menilai seberapa jauh perusahaan mampu mencapai tujuan perusahaan untuk meningkatkan nilai dari modal yang telah ditanamkan pemegang saham dalam operasi perusahaan. Selain melalui analisis rasio yang biasanya telah dicantumkan dalam pelaporan keuangan, investor dapat lebih yakin menanamkan modalnya dengan melihat nilai EVA pada perusahaan.
Berdasarkan uraian di atas, maka penulis tertarik untuk mengetahui kinerja perusahaan telekomunikasi yang tercatat di Bursa Efek Indonesia, dikaji dengan metode Economic Value Added (EVA). Dengan demikian penulis mengangkat judul penelitian "Analisis Kinerja Keuangan Berdasarkan Metode Economic Value Added (EVA) Studi Pada Perusahaan Telekomunikasi yang Tercatat di Bursa Efek Indonesia Tahun 2013".

\section{METODE}

Penelitian ini termasuk dalam penelitian deskriptif dengan pendekatan kuantitatif. Penelitian ini memaparkan kinerja keuangan perusahaan telekomunikasi yang telah tercatat di Bursa Efek Indonesia (BEI) tahun 2013 yang dikaji dengan analisis EVA. Data yang digunakan dalam penelitian ini berupa laporan keuangan perusahaan, harga saham masing-masing perusahaan, tingkat suku bunga SBI, dan IHSG tahun 2013 dari masingnmasing perusahaan telekomunikasi yang sudah tercatat di Bursa Efek Indonesia (BEI), data yang diperoleh dapat memberikan gambaran tentang penilaian kinerja keuangan dengan menggunakan metode Economic Value Added (EVA). Subjek dalam penelitian ini adalah perusahaan telekomunikasi yang terdaftar di Bursa Efek Indonesia tahun 2013, yaitu PT Telkomunikasi Indonesia Tbk., PT Indosat Tbk., PT Smartfren Tbk., PT XL Axiata Tbk., dan PT Bakrie Telecom Tbk. Objek dalam penelitian ini adalah data suku bunga bebas risiko, harga saham biasa, IHSG, serta data yang diperoleh dari laporan keuangan perusahaan pada tahun 2013.

Sumber data yang digunakan dalam penelitian ini adalah berupa data sekunder. Data sekunder berupa data laporan keuangan perusahaan telekomunikasi yang telah dipublikasikan di BEI dengan mengakses www.idx.co.id. Tingkat suku bunga bebas risiko yang tercatat di Bank Indonesia dapat diperoleh dengan mengakses www.bi.go.id. Harga saham 
biasa serta IHSG yang tercatat pada tahun 2013 diperoleh dengan mengakses www.duniainvestasi.com. Jenis data yang digunakan pada penelitian ini yaitu data kuantitaif. Teknik pengumpulan data yang digunakan dalam penelitian ini yaitu dokumentasi. Dokumentasi dipergunakan untuk mengumpulkan dokumen-dokumen atau arsip-arsip berupa laporan keuangan perusahaan telekomunikasi yang diperoleh dengan mengakses www.idx.co.id. Tingkat suku bunga bebas risiko diperoleh dengan mengakses www.bi.go.id. Harga saham biasa dan IHSG diperoleh dengan mengakses www.duniainvestasi.com.

Metode analisis data yang digunakan adalah analisis EVA. EVA merupakan indikator tentang adanya penambahan nilai dari suatu investasi. EVA yang positif menunjukkan bahwa manajemen perusahaan berhasil meningkatkan nilai perusahaan, sehingga mencerminkan bahwa kinerja keuangan perusahaan telah berjalan dengan baik. Secara sederhana indikator EVA dapat dijabarkan sebagai berikut.

a) Jika EVA > 0, hal ini menunjukkan terjadi nilai tambah ekonomis bagi perusahaan.

b) Jika EVA < 0, hal ini menunjukkan tidak terjadi nilai tambah ekonomis bagi perusahaan.

c) Jika EVA = 0, hal ini menunjukkan posisi "impas" karena laba telah digunakan untuk membayar kewajiban kepada penyandang dana baik kreditur maupun pemegang saham.

\section{HASIL DAN PEMBAHASAN \\ HASIL \\ Nilai Net Operating Profit After Tax (NOPAT) Pada Perusahaan Telekomunikasi Yang Tercatat Di Bursa Efek Indonesia Tahun 2013}

Analisis NOPAT adalah suatu analisis tingkat keuntungan yang diperoleh dari modal yang ditanam dengan biaya modal yang ditanamkan perusahaan. NOPAT dapat diketahui melalui rumus laba sebelum pajak dikurangi beban pajak. Perhitungan nilai NOPAT dari perusahaan telekomunikasi yang telah terdaftar di Bursa Efek (BEl) dapat dijabarkan sebagai berikut (perhitungan dalam jutaan rupiah).

a. NOPAT PT Telekomunikasi Indonesia Tbk. NOPAT $=$ EBIT - Pajak

6.859 .000

$$
=R p 27.846 .000-R p
$$

$$
=\operatorname{Rp} 20.987 .000
$$

Dari perhitungan NOPAT PT Telekomunikais Indonesia Tbk., dapat diketahui PT Telekomunikasi Indonesia Tbk. tahun 2013 telah mampu menciptakan laba setelah pajak sebesar Rp 20.987.000.000.000,00.

$$
\begin{aligned}
& \text { b. NOPAT PT Indosat Tbk. } \\
& \begin{aligned}
\text { NOPAT } & =\text { EBIT }- \text { Pajak } \\
& =\text { Rp } 1.509 .216-\text { Rp } 667.378 \\
& =\text { Rp } 841.838
\end{aligned}
\end{aligned}
$$

Dari perhitungan NOPAT PT Indosat Tbk,, dapat diketahui PT Indosat Tbk. tahun 2013 mampu menghasilkan laba setelah pajak sebesar Rp $841.838 .000 .000,00$

c. NOPAT PT Smartfren Tbk.

$$
\begin{aligned}
\text { NOPAT } & =\text { EBIT }- \text { Pajak } \\
& =\mathrm{Rp} \quad-1.611 .087,13 \quad-\quad \mathrm{Rp} \\
173.595,77 & \\
& =\operatorname{Rp}(1.784 .682,91)
\end{aligned}
$$

Dari perhitungan NOPAT PT Smartfren Tbk,, dapat diketahui PT Smartfren Tbk. tahun 2013 mengalami kerugian setelah pajak sebesar $\mathrm{Rp}$ $(1.784 .682 .909 .136,00)$.

$$
\begin{aligned}
& \text { d NOPAT PT XL Axiata Tbk. } \\
& \begin{aligned}
\text { NOPAT } & =\text { EBIT }- \text { Pajak } \\
& =\text { Rp } 1.658 .288-\text { Rp } 356.850 \\
& =\text { Rp } 1.301 .438
\end{aligned}
\end{aligned}
$$

Dari perhitungan NOPAT PT XL Axiata Tbk, dapat diketahui PT XL Axiata Tbk. tahun 2013 mampu menghasilkan laba setelah pajak sebesar Rp 1.301.438.000.000,00

$$
\begin{aligned}
& \text { e. NOPAT PT Bakrie Telecom Tbk. } \\
& \begin{aligned}
\text { NOPAT } & =\text { EBIT }- \text { Pajak } \\
& =\operatorname{Rp~} 50.380,23-\operatorname{Rp} 23.060,05 \\
& =\operatorname{Rp} 27.320 .180 .033
\end{aligned}
\end{aligned}
$$


Dari perhitungan NOPAT PT Bakrie Telecom Tbk,, dapat diketahui PT Bakrie Telecom Tbk. tahun 2013 mampu menghasilkan laba setelah pajak sebesar Rp 27.320.180.033,00

Nilai Biaya Modal Pada Perusahaan Telekomunikasi Yang Tercatat Di Bursa Efek Indonesia Da Tahun 2013

Perusahaan telekomunikasi yang telah tercatat di BEI memiliki struktur modal yang terdiri dari modal sendiri, utang dan saham. Untuk mempertimbangkan proporsi penggunaan dana, maka manajemen menggunakan perhitungan biaya modal rata-rata tertimbang atau dikenal dengan WACC (Weighted Average Cost of Capital). WACC dapat dihitung dengan beberapa tahapan yang dijabarkan sebagai berikut.

a. Menghitung Biaya Hutang $\left(\mathrm{K}_{\mathrm{d}}\right)$

Biaya hutang dapat dihitung dengan rumus:

$$
\begin{aligned}
\mathrm{K}_{\mathrm{d}}= & \mathrm{K}_{\mathrm{d}^{*}}(1-\mathrm{T}) \\
& \text { Keterangan: } \\
& \mathrm{K}_{\mathrm{d}^{*}}=\text { Suku Bunga } \\
& \mathrm{K}_{\mathrm{d}}=\text { Biaya utang sebelum } \\
& \text { pajak } \\
& \mathrm{T}=\text { Tarif pajak }
\end{aligned}
$$

\begin{tabular}{|c|c|c|c|c|c|}
\hline Keterangan & TLKM & ISAT & FREN & EXCL & BTEL \\
\hline Beban Bunga & 1.504 .000 & 2.212 .095 & $390.141,61$ & 998.211 & $155.349,20$ \\
\hline Hutang Jk. Panjang & 22.090 .000 & 24.508 .856 & $7.276 .998,05$ & 17.046 .433 & 4.197.141 \\
\hline $\begin{array}{l}\text { Suku Bunga }\left(\mathrm{Kd}^{*}\right) \% \\
\text { Trf. Pajak Perusahaan }\end{array}$ & 0,0681 & 0,0903 & 0,0536 & 0,0586 & 0,0370 \\
\hline$\%$ & 20 & 25 & 20 & 20 & 20 \\
\hline $1-t \%$ & 80 & 75 & 80 & 80 & 80 \\
\hline $\mathrm{Kd} \%$ & 5,4468085 & 6,76927 & 4,28904 & 4,68467 & 2,96105 \\
\hline
\end{tabular}

Suku bunga dapat dihitung dengan rumus:

$$
\begin{array}{ll}
\mathrm{K}_{\mathrm{d}^{*}}= & \multicolumn{3}{c}{\text { Beban Bunga }} \\
\text { Perhitungan } & \begin{array}{l}
\text { Hutang Jangka Panjang } \\
\text { suku bunga dapat }
\end{array} \\
\text { dijabarkan } & \begin{array}{l}
\text { pada } \\
\text { pabel }
\end{array}
\end{array}
$$

Tabel 1 Perhitungan Suku Bunga Perusahaan Telekomunikasi di BEI

Berdasarkan hasil perhitungan tabel 1, dapat diketahui jumlah biaya hutang untuk PT Telekomunikasi Indonesia Tbk sebesar 5,45\%, PT Indosat Tbk memiliki biaya hutang sebesar $6,77 \%$, PT Smartfren memiliki biaya hutang sebesar 4,29\%, PT XL Axiata memiliki biaya hutang sebesar 4,68\%, dan PT Bakrie Telecom memiliki biaya hutang sebesar $2,96 \%$.

b. Menghitung Biaya Ekuitas $\left(\mathrm{K}_{\mathrm{e}}\right)$ Dalam perhitungan biaya ekuitas digunakan pendekatan Capital Assets Pricing Models (CAPM). CAPM menggambarkan keadaan pasar secara riil, di mana tingkat pengembalian saham yang diinginkan investor sama dengan tingkat suku bunga bebas resiko ditambah dengan premi resiko. Pendekatan CAPM dapat dirumuskan sebagai berikut.

$$
K_{e}=R_{f}+\beta\left(R_{m}-R_{f}\right)
$$

Keterangan:

$\mathrm{K}_{\mathrm{e}}=$ Biaya modal

$R_{f}=$ Tingkat pengembalian bebas risiko (rata-rata suku bunga SBI)

$\beta=$ beta, pengukuran sistematis sah

$R_{m}=$ Tingkat pengembalian pasar

Sebelum menghitung biaya modal, maka harus diketahui tingkat pengembalian bebas resiko $\left(R_{f}\right)$, tingkat pengembalian pasar $\left(R_{m}\right)$, dan beta $(\beta)$. Ketiga komponen tersebut dapat dihitung dengan cara sebagai berikut.

a) Tingkat Pengembalian Bebas Resiko $\left(\mathrm{R}_{\mathrm{f}}\right)$

Tingkat pengembalian bebas resiko diperoleh dari rata-rata bunga Sertifikat Bank Indonesia (SBI) selama tahun 2013 dapat diketahui dari Tabel 2. 
Tabel 2 Tingkat Pengembalian Bebas Resiko Tahun 2013

\begin{tabular}{|c|c|}
\hline BULAN & $\mathbf{R}_{\mathrm{f}}$ \\
\hline Januari & $7,50 \%$ \\
\hline Februari & $7,50 \%$ \\
\hline Maret & $7,25 \%$ \\
\hline April & $7,25 \%$ \\
\hline Mei & $7,00 \%$ \\
\hline Juni & $6,50 \%$ \\
\hline Juli & $6,00 \%$ \\
\hline Agustus & $5,75 \%$ \\
\hline September & $5,75 \%$ \\
\hline Oktober & $5,75 \%$ \\
\hline November & $5,75 \%$ \\
\hline Desember & $5,75 \%$ \\
\hline JUMLAH & $77,75 \%$ \\
\hline Rata-Rata & $6,48 \%$ \\
\hline
\end{tabular}

Dari Tabel 2 dapat diketahui tingkat pengembalian bebas resiko tahun 2013 yaitu $6,48 \%$.

b) Tingkat Pengembalian Pasar $\left(R_{m}\right)$

Tingkat pengembalian pasar $\left(R_{m}\right)$ diperoleh dari rata-rata Indeks Harga Saham Gabungan (IHSG) setiap bulan

$$
\mathrm{R}_{\mathrm{m}}=\frac{\mathrm{IHSG}_{t}-\mathrm{IHSG}_{t-1}}{\ldots \ldots \ldots . .(1)} I_{\mathrm{HSG}}
$$
$\mathrm{R}_{\mathrm{m}} \quad=$ Tingkat pengembalian pasar $\mathrm{IHSG}_{\mathrm{t}} \quad=$ Harga penutupan IHSG akhir hari transaksi bulan ini

$\mathrm{IHSG}_{\mathrm{t}-1}=$ Harga penutupan IHSG akhir bulan lalu selama tahun 2013. $R_{m}$ dapat dihitung dengan rumus :

Tabel 3 Tingkat Pengembalian Pasar Tahun 2013

\begin{tabular}{|c|c|c|}
\hline BULAN & IHSG & $\mathbf{R m}$ \\
\hline Des. 2012 & 4316,687 & \\
\hline Januari, 2013 & 4453,703 & 0,03174 \\
\hline Februari & 4795,789 & 0,07681 \\
\hline Maret & 4940,986 & 0,03028 \\
\hline April & 5034,071 & 0,01884 \\
\hline Mei & 5068,628 & 0,00686 \\
\hline Juni & 4818,895 & $-0,04927$ \\
\hline Juli & 4610,377 & $-0,04327$ \\
\hline Agustus & 4195,089 & $-0,09008$ \\
\hline September & 4316,176 & 0,02886 \\
\hline Oktober & 4510,631 & 0,04505 \\
\hline November & 4256,436 & $-0,05635$ \\
\hline Desember & 4274,177 & 0,00417 \\
\hline JUMLAH & 55274,958 & 0,00364 \\
\hline Rata-rata & 4606,2465 & 0,0003 \\
\hline & & $R_{i}=\frac{P_{t}-P_{t-1}}{}$ \\
\hline
\end{tabular}

Dari Tabel 3. dapat diketahuin 2013 yaitu 0,0003 .

Keterangan:

c) Tingkat Pengembalian Individu $\left(\mathrm{R}_{\mathrm{i}}\right)$

Tingkat pengembalian individual dihitung dari harga saham tiap bulan selama kurun waktu yang ditetapkan. $\mathrm{R}_{\mathrm{i}}$ dapat dihitung dengan rumus sebagai berikut.

$R_{\mathrm{i}}=$ Tingkat pengembalian individu

$P_{t}=$ Harga penutupan saham periode $t$

$\mathrm{P}_{\mathrm{t}-1}=$ Harga penutupan saham periode sebelum periode $t$

Adapun hasil perhitungan $\mathrm{Ri}$ dapat dijabarkan pada Tabel 4. 
Tabel 4 Tingkat Pengembalian Individu Perusahaan Telekomunikasi di BEI tahun 2013

\begin{tabular}{lcccccccccc}
\hline \multirow{2}{*}{ BULAN } & \multicolumn{2}{c}{ TLKM } & \multicolumn{2}{c}{ ISAT } & \multicolumn{2}{c}{ FREN } & \multicolumn{2}{c}{ EXCL } & \multicolumn{3}{c}{$B T E L$} \\
\cline { 2 - 11 } & $\mathrm{P}$ & $\mathrm{R}_{\mathrm{i}}$ & $\mathrm{P}$ & $\mathrm{R}_{\mathrm{i}}$ & $\mathrm{P}$ & $\mathrm{R}_{\mathrm{i}}$ & $\mathrm{P}$ & $\mathrm{R}_{\mathrm{i}}$ & $\mathrm{P}$ & $\mathrm{R}_{\mathrm{i}}$ \\
\hline Des. 2012 & 1940 & 0,0718 & 6800 & 0,0543 & 90 & 0,0714 & 5000 & $-0,1228$ & 50 & 0 \\
Januari,2013 & 2150 & 0,1082 & 6350 & $-0,0662$ & 92 & 0,0222 & 5450 & 0,0900 & 50 & 0 \\
Februari & 2200 & 0,0233 & 6500 & 0,0236 & 95 & 0,0326 & 5250 & $-0,0367$ & 50 & 0 \\
Maret & 2340 & 0,0636 & 6000 & $-0,0769$ & 91 & $-0,0421$ & 5100 & $-0,0286$ & 50 & 0 \\
April & 2210 & $-0,0556$ & 5200 & $-0,1333$ & 85 & $-0,0659$ & 5000 & $-0,0196$ & 50 & 0 \\
Mei & 2250 & 0,0181 & 5250 & 0,0096 & 73 & $-0,1412$ & 4825 & $-0,0350$ & 50 & 0 \\
Juni & 2380 & 0,0578 & 5000 & $-0,0476$ & 73 & 0,0000 & 4500 & $-0,0674$ & 50 & 0 \\
Juli & 2200 & $-0,0756$ & 4125 & $-0,1750$ & 59 & $-0,1918$ & 4475 & $-0,0056$ & 50 & 0 \\
Agustus & 2100 & $-0,0455$ & 4150 & 0,0061 & 61 & 0,0339 & 4250 & $-0,0503$ & 50 & 0 \\
September & 2350 & 0,1190 & 4400 & 0,0602 & 65 & 0,0656 & 4475 & 0,0529 & 50 & 0 \\
Oktober & 2175 & $-0,0745$ & 3850 & $-0,1250$ & 50 & $-0,2308$ & 5000 & 0,1173 & 50 & 0 \\
November & 2150 & $-0,0115$ & 4150 & 0,0779 & 54 & 0,0800 & 5200 & 0,0400 & 50 & 0 \\
Desember & $\mathbf{2 6 4 4 5}$ & $\mathbf{0 , 1 9 9 3}$ & $\mathbf{6 1 7 7 5}$ & $\mathbf{- 0 , 3 9 2 3}$ & $\mathbf{8 8 8}$ & $-\mathbf{0 , 3 6 6 0}$ & $\mathbf{5 8 5 2 5}$ & $\mathbf{- 0 , 0 6 5 6}$ & $\mathbf{6 0 0}$ & $\mathbf{0}$ \\
\hline JUMLAH & $\mathbf{2 2 0 3 , 7 5}$ & $\mathbf{0 , 0 1 6 6}$ & $\mathbf{5 1 4 7 , 9}$ & $\mathbf{- 0 , 0 3 2 7}$ & $\mathbf{7 4}$ & $\mathbf{- 0 , 0 3 0 5}$ & $\mathbf{4 8 7 7 , 1}$ & $\mathbf{- 0 , 0 0 5 5}$ & $\mathbf{5 0}$ & $\mathbf{0}$ \\
\hline Rata-Rata & 1940 & $\mathbf{0 , 0 7 1 8}$ & $\mathbf{6 8 0 0}$ & $\mathbf{0 , 0 5 4 3}$ & $\mathbf{9 0}$ & $\mathbf{0 , 0 7 1 4}$ & $\mathbf{5 0 0 0}$ & $-0,1228$ & $\mathbf{5 0}$ & 0 \\
\hline
\end{tabular}

Berdasarkan hasil perhitungan tabel 4, dapat diketahui tingkat pengembalian individu tahun 2013 untuk PT Telekomunikasi Indonesia Tbk sebesar 0,0166, PT Indosat Tbk memiliki tingkat pengembalian individu sebesar -0,0327, PT Smartfren memiliki tingakat pengembalian individu sebesar $-0,0305$ PT XL Axiata memiliki tingakat pengembalian individu sebesar $-0,0055$, dan PT Bakrie Telecom memiliki tingakat pengembalian individu sebesar 0. d) Beta ( $\beta$ )

Beta dapat dirumuskan sebagai berikut.

$$
\beta=\frac{(n . \Sigma X Y)-[(\Sigma X)(\Sigma Y)]}{\left[n(\Sigma X)^{2}\right]-\Sigma X^{2}}
$$

Keterangan:

$X=$ Tingkat pengembalian pasar $\left(R_{m}\right)$

$\mathrm{Y}=$ Tingkat keuntungan saham atau pengembalian individu $\left(\mathrm{R}_{\mathrm{i}}\right)$

Dari hasil perhitungan rumus di atas, komponen $X$ berasal dari tingkat pengembalian saham $\left(R_{m}\right)$ dan komponen $Y$ berasal dari tingkat pengembalian individu $\left(R_{i}\right)$ maka perhituangan dapat dilihat pada Tabel 5.

Tabel 5 Hasil perhitungan beta Perusahaan Telekomunikasi tahun 2013

\begin{tabular}{lccccc}
\hline Keterangan & $\mathbf{X}(\mathbf{R m})$ & $\mathbf{Y}(\mathbf{R i})$ & $\mathbf{X . Y}$ & $\mathbf{X}^{\mathbf{2}}$ & $\mathbf{B e t a}$ \\
\hline TLKM & 0,0036 & 0,1993 & 0,0237 & 0,0267 & $-0,862$ \\
ISAT & 0,004 & $-0,392$ & 0,023 & 0,027 & $-0,9$ \\
FREN & 0,0036 & $-0,3660$ & 0,0452 & 0,0267 & $-1,745$ \\
EXCL & 0,0036 & $-0,066$ & 0,0009 & 0,026696 & $-0,0412$ \\
BTEL & 0,004 & 0,000 & 0,000 & 0,02670 & 0,02668 \\
\hline
\end{tabular}

Setelah diketahui komponen biaya modal, maka dapat dihitung nilai dari biaya modal dengan rumus $K_{e}=R_{f}+\beta\left(R_{m}-R_{f}\right)$ ditunjukan pada Tabel 6 di bawah ini. 
Tabel 6 Perhitungan Biaya Ekuitas (Ke) Perusahaan Telekomunikasi Di BEI Tahun 2013

\begin{tabular}{lccrrr}
\hline Keterangan & TLKM & \multicolumn{1}{c}{ ISAT } & FREN & \multicolumn{1}{c}{ EXCL } & \multicolumn{1}{c}{ BTEL } \\
\hline $\mathbf{R f}$ & 0,0648 & 0,0648 & 0,0648 & 0,0648 & 0,0648 \\
$\mathbf{R m}$ & 0,0003 & 0,0003 & 0,0003 & 0,0003 & 0,0003 \\
$\mathbf{B}$ & $-0,862$ & $-0,9$ & $-1,745$ & $-0,0412$ & 0,02668 \\
\hline $\mathbf{K e}$ & 0,1204 & 0,1228 & 0,1773 & 0,0675 & 0,0631 \\
\hline
\end{tabular}

Dari perhitungan pada tabel 6, dapat diketahui biaya ekuitas PT Telekomunikasi Indonesia Tbk tahun 2013 sebesar 0,1204, biaya modal PT Indosat Tbk sebesar 0,1228 . biaya modal PT Smartfren Tbk tahun 2013 sebesar 0,02668, biaya ekuitas PT XL Axiata Tbk sebesar 0,0675 , dan biaya modal PT Bakrie Telecom Tbk sebesar 0,0631 . c. Menghitung Proporsi Hutang $\left(\mathrm{W}_{\mathrm{d}}\right)$

Proposi hutang diperoleh dengan rumus berikut.

$\mathrm{W}_{\mathrm{d}}=\frac{\text { Hutang jangka panjang }}{\text { Total Aset }}$

Perhitungan proporsi hutang untuk perusahaan telekomunikasi yang tercatat di BEI dapat dijabarkan pada Tabel 7.

Tabel 7 Perhitungan Proporsi Hutang (dalam jutaan rupiah)

\begin{tabular}{lrrrrr}
\hline Keterangan & \multicolumn{1}{c}{ TLKM } & \multicolumn{1}{c}{ ISAT } & \multicolumn{1}{c}{ FREN } & \multicolumn{1}{c}{ EXCL } & \multicolumn{1}{c}{ BTEL } \\
\hline Hutang Jk Panjang & 22.090 .000 & 24.508 .856 & $7.276 .998,05$ & 17.046 .433 & $4.197 .140,53$ \\
Total Aset & 127.951 .000 & 54.520 .891 & $15.866 .493,43$ & 40.277 .626 & $8.893 .703,94$ \\
\hline $\mathbf{W}_{\mathbf{d}}$ & $\mathbf{0 , 1 7 3}$ & $\mathbf{0 , 4 5}$ & $\mathbf{0 , 4 5 9}$ & $\mathbf{0 , 4 2 3}$ & $\mathbf{0 , 4 7}$ \\
\hline
\end{tabular}

Dari tabel 7 dapat dijelaskan, PT

Telekomunikasi Indonesia Tbk memiliki tingkat proporsi hutang sebesar 0,17 . PT Indosat Tbk. memiliki proporsi hutang sebesar 0,45. Proporsi hutang PT Smartfren Tbk. sebesar 0,46. Proporsi hutang PT XL Axiata Tbk. sebesar 0,42, sedangkan proporsi hutang PT Bakrie Telecom sebesar 0,46 . d. Menghitung Proporsi Modal $\left(\mathrm{W}_{\mathrm{e}}\right)$

Proporsi hutang diperoleh dengan rumus sebagai berikut.

$$
\mathrm{W}_{\mathrm{e}}=\frac{\text { Ekuitas }}{\text { Total aset }}
$$

Perhitungan proporsi hutang untuk perusahaan telekomunikasi yang tercatat di BEI tahun 2013 dapat dijabarkan Tabel 8.

Tabel 8 Perhitungan Proporsi Modal (dalam jutaan rupiah)

\begin{tabular}{lrrrrr}
\hline Keterangan & \multicolumn{1}{c}{ TLKM } & \multicolumn{1}{c}{ ISAT } & \multicolumn{1}{c}{ FREN } & \multicolumn{1}{c}{ EXCL } & \multicolumn{1}{c}{ BTEL } \\
\hline Ekuitas & 77.424 .000 & 16.517 .598 & $3.049 .944,95$ & 15.300 .147 & $1.540 .511,02$ \\
Total Aset & 127.951 .000 & 54.520 .891 & $15.866 .493,43$ & 40.277 .626 & $8.893 .703,94$ \\
\hline $\mathbf{W}_{\mathbf{e}}$ & $\mathbf{0 , 6 0 5}$ & $\mathbf{0 , 3 0 3}$ & $\mathbf{0 , 1 9 2}$ & $\mathbf{0 , 3 8}$ & $\mathbf{0 , 1 7 3}$ \\
\hline
\end{tabular}

Dari tabel 8 dapat dijelaskan, PT Telekomunikasi Indonesia Tbk memiliki tingkat proporsi hutang sebesar 0,605. PT Indosat Tbk. memiliki proporsi hutang sebesar 0,303. Proporsi hutang PT Smartfren Tbk. sebesar 0,192. Proporsi hutang PT XL Axiata Tbk. sebesar 0,38, sedangkan proporsi hutang PT Bakrie Telecom sebesar 0,173 . e. Weighted Average Cost of Capital (WACC)

Berdasarkan hasil biaya modal dan biaya hutang, maka besarnya biaya modal rata-rata tertimbang dapat dihitung dengan rumus sebagai berikut.

$W A C C=W_{d} \cdot K_{d}(1-T)+W_{e} \cdot K_{e}$

Keterangan:

WACC = Biaya modal rata-rata tertimbang 


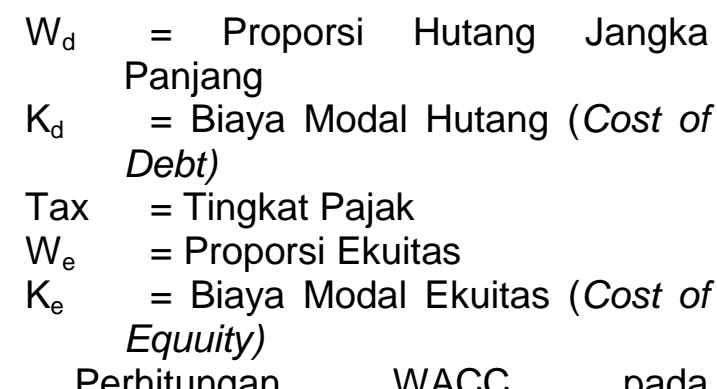

Perhitungan WACC pada perusahaan yang bergerak di bidang telekomunikasi yang sudah tercatat di BEI dapat dijelaskan di jabarkan sebagai berikut.

a). PT Telekomunikasi Indonesia Tbk. $W A C C=W_{d} \cdot K_{d}(1-T)+W_{e} \cdot K_{e}$ $=0,173 \times 0,0545(1-0,2)+0,605 \times$ 0,1204 $=0,0804$

Berdasarkan hasil perhitungan di atas, maka besarnya biaya modal ratarata tertimbang PT Telekomunikasi Indonesia Tbk. tahun 2013 adalah $8,04 \%$.

b). PT Indosat Tbk.

$\mathrm{WACC}=\mathrm{W}_{\mathrm{d}} \cdot \mathrm{K}_{\mathrm{d}}(1-\mathrm{T})+\mathrm{W}_{\mathrm{e}} \cdot \mathrm{K}_{\mathrm{e}}$ $=0,45 \times 0,0677(1-0,25)+0,303 \times$

0,1229

$=0,06004$

Berdasarkan hasil perhitungan di atas, maka besarnya biaya modal ratarata tertimbang PT Indosat Tbk. tahun 2013 adalah 6,004\%. c). PT Smartfren Tbk.

$\mathrm{WACC}=\mathrm{W}_{\mathrm{d}} \cdot \mathrm{K}_{\mathrm{d}}(1-\mathrm{T})+\mathrm{W}_{\mathrm{e}} \cdot \mathrm{K}_{\mathrm{e}}$ $=0,459 \times 0,0429(1-0,2)+0,192 \times$ 0,1773

$=0,0498$

Berdasarkan hasil perhitungan di atas, maka besarnya biaya modal ratarata tertimbang $\mathrm{PT}$ Smartfren Tbk. tahun 2013 adalah 4,98\%.

d). PT XL Axiata Tbk.

$W A C C=W_{d} \cdot K_{d}(1-T)+W_{e} \cdot K_{e}$ $=0,423 \times 0,0468(1-0,2)+0,38 \times$ 0,0674

$=0,0415$

Berdasarkan hasil perhitungan di atas, maka besarnya biaya modal ratarata tertimbang PT XL Axiata Tbk. tahun 2013 adalah 4,15\%.

e). PT Bakrie Telecom Tbk.

$\mathrm{WACC}=\mathrm{W}_{\mathrm{d}} \cdot \mathrm{K}_{\mathrm{d}}(1-\mathrm{T})+\mathrm{W}_{\mathrm{e}} \cdot \mathrm{K}_{\mathrm{e}}$ $=0,47 \times 0,0296(1-0,2)+0,173 \times 0,0631$ $=0,0221$

Berdasarkan hasil perhitungan di atas, maka besarnya biaya modal ratarata tertimbang PT Bakrie Telecom Tbk. tahun 2013 adalah 2,21\%.

Dari hasil perhitungan WACC diatas, maka diperoleh biaya modal perusahaan telekomunikasi yang tercatat di BEI yang dapat dijabarkan pada Tabel 9.

Tabel 9 Perhitungan Biaya Modal (dalam jutaan rupiah)

\begin{tabular}{lccccc}
\hline Keterangan & TLKM & ISAT & FREN & EXCL & BTEL \\
\hline Total Aset & 127.951 .000 & 54.520 .891 & $15.866 .493,43$ & 40.277 .626 & $8.893 .703,94$ \\
WACC (\%) & 8,04 & 6,004 & 4,98 & 4,15 & 2,21 \\
\hline Biaya Modal & $\mathbf{1 0 . 2 8 4 . 8 4 8 , 5 5}$ & $\mathbf{3 . 2 7 3 . 7 0 1 , 1 6}$ & $\mathbf{7 9 0 . 4 4 1 , 7 1}$ & $\mathbf{1 . 6 7 0 . 8 0 0 , 5 6}$ & $\mathbf{1 9 6 . 5 8 5 , 0 1}$ \\
\hline
\end{tabular}

Dari tabel 9 dapat dijelaskan, PT Telekomunikasi Indonesia Tbk. tahunn 2013 memiliki biaya modal sebesar Rp 10.284.848.546.016,00. PT Indosat Tbk. tahun 2013 memiliki biaya modal sebesar Rp 3.273.701.158.489,00. Biaya modal PT Smartfren Tbk. tahun 2013 sebesar Rp 790.441.706.857,00. Biaya modal PT XL Axiata Tbk. tahun 2013 sebesar Rp 1.670.800.564.235,00, sedangkan biaya modal PT Bakrie Telecom Tbk. tahun 2013 sebesar Rp 196.585.006.260,00.

\section{Analisis EVA (Economic Value Added)}

Perhitungan nilai EVA pada perusahaan telekomunikasi yang tercatat di BEI dapat dijabarkan sebagai berikut (perhitungan dalam jutaan rupiah\}. 
a. PT Telekomunikasi Indonesia Tbk.

EVA $=$ NOPAT - Biaya Modal

$$
=20.987 .000-10.284 .848,55
$$$$
=10.702 .151,45
$$

Berdasarkan hasil perhitungan di atas, maka besarnya nilai EVA PT Telekomunikasi Indonesia Tbk. tahun 2013 adalah $\mathrm{Rp}$ 10.702.151.453.984,00. Nilai EVA > 0, ini menjelaskan bahwa kinerja keuangan PT Telekomunikasi Indonesia Tbk. sudah bekerja dengan baik karena telah mampu menciptakan nilai tambah bagi perusahaan.

b. PT Indosat Tbk.

$$
\begin{aligned}
\text { EVA } & =\text { NOPAT }- \text { Biaya Modal } \\
& =841.838-3.273 .701,16 \\
& =-2.431 .863,16
\end{aligned}
$$

Berdasarkan hasil perhitungan di atas, maka besarnya nilai EVA PT Indosat Tbk. tahun 2013 adalah Rp 2.431.863.158.489,00. Nilai EVA < 0 , ini menunjukkan tidak terjadi nilai tambah ekonomis bagi perusahaan. Ini mencerminkan bahwa kinerja keuangan perusahaan belum bekerja secara maksimal sehingga tidak mampu menciptakan nilai tambah bagi perusahaan.

c. PT Smartfren Tbk.

$$
\begin{aligned}
\text { EVA } & =\text { NOPAT }- \text { Biaya Modal } \\
& =-1.784 .682,91-790.441,71 \\
& =-2.575 .124,62
\end{aligned}
$$

Berdasarkan hasil perhitungan di atas, maka besarnya nilai EVA PT Smartfren Tbk. tahun 2013 adalah Rp 2.575.124.615.993,00. Nilai EVA < 0, ini menunjukkan tidak terjadi nilai tambah ekonomis bagi perusahaan. Ini mencerminkan bahwa kinerja keuangan perusahaan belum bekerja secara maksimal sehingga tidak mampu menciptakan nilai tambah bagi perusahaan.

d. PT XL Axiata Tbk.

$$
\begin{aligned}
\text { EVA } & =\text { NOPAT }- \text { Biaya Modal } \\
& =1.301 .438-1.670 .800,56 \\
& =-369.362,56
\end{aligned}
$$

Berdasarkan hasil perhitungan di atas, maka besarnya nilai EVA PT XL Axiata Tbk. tahun 2013 adalah Rp -
369.362.564.235,00. Nilai EVA < 0, ini menunjukkan tidak terjadi nilai tambah ekonomis bagi perusahaan. Ini mencerminkan bahwa kinerja keuangan perusahaan belum bekerja secara maksimal sehingga tidak mampu menciptakan nilai tambah bagi perusahaan.

e. PT Bakrie Telecom Tbk.

$$
\begin{aligned}
\text { EVA } & =\text { NOPAT }- \text { Biaya Modal } \\
& =27.320,18-196.585,01 \\
& =-169.264,83
\end{aligned}
$$

Berdasarkan hasil perhitungan di atas, maka nilai EVA PT Bakrie Telecom Tbk. tahun 2013 adalah Rp 169.264.826.227,00. Nilai EVA < 0, ini menunjukkan tidak terjadi nilai tambah ekonomis bagi perusahaan. Ini mencerminkan bahwa kinerja keuangan perusahaan belum bekerja secara maksimal sehingga tidak mampu menciptakan nilai tambah bagi perusahaan.

\section{PEMBAHASAN}

Berdasarkan hasil penelitian, maka diperoleh hasil nilai NOPAT PT Telekomunikasi Indonesia Tbk. lebih besar dari biaya modal yang dimiliki perusahaan, ini menghasilkan nilai EVA PT Telekomunikasi Indonesia Tbk. tahun 2013 lebih dari 0. Sesuai dengan teori yang dikemukakan Sawir (2005), jika nilai EVA > 0, maka terjadi nilai tambah ekonomis bagi perusahaan. Terjadinya nilai tambah pada PT Telekomunikasi Indonesia Tbk. dikarenakan perusahaan mampu membiayai biaya modal perusahaan dengan laba yang diperoleh perusahaan. Penelitian dari Risky Fidianti (2011), juga mengemukakan bahwa perusahaan yang mampu membiaya biaya modalnya dengan laba bersih yang diperoleh akan menghasilkan nilai EVA yang lebih dari 0 , sehingga mencerminkan bahwa kinerja keuangan perusahaan telah berjalan dengan baik.

PT Indosat Tbk, PT Smartfren Tbk., PT XL Axiata Tbk., dan PT Bakrie Telecom Tbk. memiliki nilai NOPAT lebih kecil dari pada biaya modal, 
sehingga menghasilkan nilai EVA kurang dari 0 . Hal ini menunjukkan bahwa kinerja keuangan perusahaan belum mampu membiayai biaya modal perusahaan dengan laba bersih yang dihasilkan perusahaan. Sesuai dengan teori yang dikemukakan oleh Sawir (2005), bahwa nilai EVA<0 menjelaskan bahwa tidak terjadi nilai tambah ekonomis bagi perusahaan, sehingga ini menunjukkan bahwa kinerja keuangan belum bekerja dengan baik. Hasil penelitian ini juga sesuai dengan hasil penelitian Risky Fidianti (2011) bahwa kinerja keuangan dinyatakan kurang berjalan dengan baik karena perusahaan belum mampu membiayai biaya modal perusahaan dengan laba bersih yang diperoleh perusahaan.

\section{SIMPULAN DAN SARAN SIMPULAN}

Berdasarkan analisis data pada bab empat, maka dapat disimpulkan bahwa hasil analisis NOPAT perusahaan telekomunikasi yang telah tercatat di BEI tahun 2013 menunjukkan kemampuan perusahaan menghasilkan laba bagi perusahaan. PT Telekomunikasi Indonesia Tbk. tahun 2013 mampu menghasilkan laba setelah pajak sebesar $R p$ 20.987.000.000.000,00. PT Indosat Tbk. tahun 2013 mampu menghasilkan laba setelah pajak sebesar $\mathrm{Rp}$ 841.838.000.000,00, PT Smartfren Tbk. tahun 2013 mampu menghasilkan laba setelah pajak sebesar Rp 1.784.682.909.136,00, PT XL Axiata Tbk. tahun 2013 mampu menghasilkan laba setelah pajak sebesar $\mathrm{Rp}$ 1.301.438.000.000,00, dan PT Bakrie Telecom tahun 2013 mampu menghasilkan laba setelah pajak sebesar Rp 27.320.180.033,00.

Hasil analisis biaya modal perusahaan telekomunikasi yang telah tercatat di BEI tahun 2013 menunjukkan biaya yang dikeluarkan perusahaan untuk pendanaan kegiatan perusahaan. PT Telekomunikasi Indonesia Tbk. tahun 2013 memiliki biaya modal sebesar Rp 10.284.848.546.016,00. PT Indosat Tbk. tahun 2013 memiliki biaya modal sebesar

$\mathrm{Rp}$

3.273.701.158.489,00. PT Smartfren Tbk. tahun 2013 memiliki biaya modal sebesar Rp 790.441.706.857,00. PT XL Axiata Tbk. tahun 2013 memiliki biaya modal sebesar Tbk. Rp 1.670.800.564.235,00, dan biaya modal PT Bakrie Telecom tahun 2013 sebesar Rp 196.585.006.260,00.

Dari hasil analisis EVA, kinerja keuangan PT Telekomunikasi Indonesia telah berjalan dengan baik. Ini ditunjukan dari nilai EVA PT Telekomunikasi Indonesia tahun 2013 lebih dari 0. PT Indosat Tbk., PT Smartfren Tbk., PT XL Axiata Tbk. dan PT Bakrie Telecom Tbk. memiliki nilai EVA kurang dari 0 , ini menunjukkan kinerja keuangan perusahaan belum mampu menciptakan nilai tambah bagi perusahaan.

\section{SARAN}

Berdasarkan uraian pada bab-bab sebelumnya dan juga pada kesimpulan, maka dapat dikemukakan saran untuk pihak perusahaan diharapkan dapat melengkapi penilaian kinerja keuangan dengan menggunakan analisis EVA selain analisis rasio keuangan yang selama ini digunakan. Untuk meningkatkan nilai EVA, sebaiknya perusahaan meningkatkan nilai operating profit perusahaan untuk mendapatkan nilai NOPAT yang tinggi. Selain itu perusahaan diharapkan mencari alternatif pembiayaan, baik hutang maupun modal yang memiliki biaya terkecil.

Saran untuk peneliti selanjutnya yang melakukan penelitian sejenis, sebaiknya menggunakan objek, periode pengamatan, dan metode yang lebih banyak, sehingga dapat memperoleh hasil penelitian yang lebih baik.

\section{DAFTAR PUSTAKA}

Anonim. 2013. Laporan Keuangan Perusahaan. Tersedia pada http:www.idx.go.id. (diakses pada 21 Juli 2014)

\section{--------. 2013. Indeks Harga Saham Gabungan dan Saham Biasa.}


Tersedia

http:www.duniainvestasi.com.

(diakses pada 21 Juli 213)

pada

2013. Tingkat Suku Bunga.

Tersedia pada http:www.bi.go.id. (diakses pada 21 Juli 213)

Arikunto, Suharsimi. 2006. Prosedur Penelitian Study Pendekatan Praktik. Edisi Revisi Enam. Jakarta: PT. Rineka Cipta.

Fahmi, Irham. 2010. Manajemen Kinerja Teori dan Aplikasi. Bandung: Alfabeta.

Fidianto, Risky. 2011. Analisis Penilaian Kinerja Keuangan dengan Pendekatan EVA pada PT Sumber Batu Gowa di Makassar. Makassar: Universitas Hasanuddin.

Halim, Abdul dan Sarwoko. 2001. Manajemen Keuangan (Dasardasar Pembelanjaan Perusahaan). Yogyakarta: YKPN.

Hanafi, M. Mahmud. 2003. Manajemen Keuangan. Yogyakarta: BPFE.

dan Abdul Halim. 2003. Analisis Laporan Keuangan. Yogyakarta: YKPN.

Handayani, Ika. 2011. Analisis Laporan Keuangan Untuk Menilai Kinerja Keuangan Perusahaan Pada Perusahaan Industri Tekstil Yang Terdaftar Di Bursa Efek Indonesia. Medan: Skripsi Fakultas Ekonomi Univeristas Sumatera Utara.

Harmono. 2009. Manajemen Keuangan Berbasis Balanceed Scorecard Pendekatan Teori, Kasus Dan Reset Bisnis. Jakarta: Bumi Aksara.

Heru Prasetyo, Aries. 2011. Valuasi Perusahaan. Jakarta: PPM
Jogiyanto. 2003. Teori Fortofolio dan Analisis Investasi. Edisi Ketiga. Yogyakarta: BPFE

Kasmir. 2008. Analisis Laporan Keuangan. Jakarta: Rajawali Pers.

Margaretha, Farah. 2007 Manajemen Keuanagan. Jakarta: Gramedia Widiasarana Indonesia.

Martono dan Agus Harjito. 2008. Manajemen Keuangan.

Yogyakarta: Ekonisia Kampus Fakultas UII.

Munawir. 2007. Analisis Laporan Keuangan. Edisi Empat. Yogyakarta: Liberty.

Riyanto, Bambang. 2001. Dasar-Dasar Pembelanjaan Perusahaan. Yogyakarta: BPFE

Sartono, Agus. 2010. Manajemen Keuangan Teori dan Aplikasi Edisi 4. Yogyakarta: BPFE.

Sawir, Agnes. 2005. Analisis Kinerja Keuangan dan Perencanaan Keuangan Perusahaan. Jakarta: PT. Gramedia Pustaka Utama.

Sukardi. 2003. Metodelogi Penelitian Pendidikan. Jakarta: PT Bumi Aksara.

Tandelilin, Eduardus. 2001. Analisis Investasi dan Manajemen Portofolio. Edisi Pertama. Yogyakarta: BPFE.

Tunggal, Amin Widjaja. 2001. Manajemen Keuangan Perusahaan. Jakarta: Raja Grafindo.

Warsono. 2003.Manajemen Keuangan Perusahaan. Edisi tiga. Jilid satu. Malang: Bayu Media Publishing.

Yuwono Sony dkk. 2003. Petunjuk Praktis Penyusunan Balance Scorecard. Jakarta: Salemba Empat 